\title{
KEKURANGAN DAN KELEBIHAN MUI (MAJELIS ULAMA' INDONESIA) DI ERA ORDE BARU
}

\author{
M. Muhtarom Ilyas*
}

\begin{abstract}
Abstrak
Awal mula berdirinya Majelis Ulama' Indonesia (MUI) bukanlah kehendak umat Islam sepenuhnya dan bukan pula kehendak dari para ulama' Islam, tetapi berdirinya $\mathrm{MUI}$ adalah kehendak dari pemerintah Indonesia pada saat itu (Orde Baru) dalam rangka menguatkan kedudukan pemerintahan di saat itu. Namun demikian setelah berdirinya MUI, terdapat kekurangan dan kelebihan dalam menfatwakan berbagai macam permasalahan yang terjadi pada kehidupan masyarakat Indonesia karena di Indonesia terdapat berbagai aliran keagamaan, bahkan dalam Islam itu sendiri terdapat beberapa madzhab yang berbeda.
\end{abstract}

Kata Kunci : : MUl, kekurangan, kelebihan.

Majelis Ulama' Indonesia (MUI) merupakan organisasi keagamaan yang ada di Indonesia yang berfungsi untuk menfatwakan hukum-hukum baik halal atau haramnya sesuatu (boleh tidaknya sesuatu).

\section{Kepengurusan MUI}

Susunan pengurus MUI terdiri dari pelindung, dewan pertimbangan, dan dewan pimpinan ( PD pasal 6 ). Untuk pelindung ditetapkan dari pejabat tertinggi ditingkat kepengurusan. Di tingkat pusat adalah Presiden. Di tingkat Daerah Tingkat I Gubenur dan Tingkat II Bupati/Wali kota ( PRT Pasal 2 ) tanpa memandang agama masing-masing. Di tingkat Pusat Dewan Pertimbangan ketuanya di jabat secara ex officio oleh Menteri Agama di tambah anggota yang terdiri dari beberapa Menteri yang berhubungan dengan pelaksanaan tugas MUI serta Ulama terkemuka serta unsur pucuk pimpinan ormas Islam serta tokoh masyarakat ( PRT Pasal 3 ayat 2 ). Pada sisi lain pengurus MUI diharuskan memenuhi kriteria sebagai berikut :

1. Warga negara Indonesia yang sehat jasmani dan rohani.

2. Beragama Islam

\footnotetext{
* Dosen pada Jurusan MKU FMIPA ITS.
}

jsh Jurnal Sosial Humaniora, Vo. 2, No. 1, Juni 2009 
3. Taqwa kepada Allah SWT.

4. Setia dan taat kepada Pancasila dan UUD 1945

5. Mempunyai keahlian di bidang keagamaan dan atau bidang ilmu pengetahuan, teknologi dan kemasyarakata serta jiwa pengabdian kepada masyarakat dan agama Islam

6. Menerima PD dan PRT, Program Kerja dan Peraturan-peraturan MUI

7. Mempunyai kesempatan ( PRT Pasal layat 4 )

Dalam kepengurusan MUI, Deliar Noer memberi komentar bahwa: "Susunan pengurus Majelis Ulama di perbaharui dengan penggantian orang-orang yang lebih dipercaya oleh pihak pemerintah. Seperti jabatan sekertaris jenderal dan sekertaris yang sebelumnya di pegang oleh orang-orang kepercayaan Hamka pada tahun 1980 di ganti dengan orang-orang yang lebih sesuai dengan pemerintah. Sekertaris jenderal yang lama ialah bekas sekertaris Jenderal Departemen Agama, Kafrawi, yang pada tahun 1980 tidak lagi mempunyai fungsi di Departemen Agama. Rupanya hal ini mempengaruhi pula fungsinya di dalam Majelis Ulama dimana ia diganti sebagai sekertaris jenderal Majelis oleh Burhani Tjokrohandoko, Direktur Jenderal Bimbingan Islam dan Urusan Haji. Burhani dikenal sebagai seorang kolonel yang sangat loyal kepada pemerintah. Seorang sekertaris Ulama yang lain mengalami nasib yang sama, malah lebih tersingkir lagi. Amiruddin Siregar, seorang pensiunan kolonel yang merupakan seorang tokoh Muhammadiyah Jakarta dan semenjak Orde Lama turut membantu Hamka dalam membina Masjid Agung Al-Azhar, tidak lagi duduk dalam kepengurusan Majelis semenjak $1980 "$

Pengunduran diri Hamka pada tahun 1981 beberapa saat sesudah dipilih kembali sebagai ketua umum MUI periode kedua karena fatwa Natal yang tidak sesuai dengan keinginan pemerintah. Pada sisi lain pengunduran diri Hamka yang tidak diikuti oleh pengurus lainnya menunjukkan pula sisi kelemahan kepengurusan MUI dalam mengeluarkan fatwa, seolah-olah hanya merupakan tanggungjawab pribadi Hamka selaku ketua umum.

Alasan pemberhentian pengurus memang bisa bermacam-macam. Yang tersurat dalam PRT Pasal 1 ayat 2 tentang berhentinya pengurus memang hanya 
karena dua alasan, yaitu karena meninggal dunia dan permintaan sendiri. Dalam pasal tersebut memang tidak ada kata-kata "diberhentikan ", namun dalam pelaksanaan diusahakan bagaimana seseorang minta berhenti seperti kasus pengunduran diri Hamka. Dari pada Menteri Agama (Alamsyah R.) yang mundur lebih baik Hamka yang mundur. Tanggapan pemerintah terhadap pengunduran diri Hamka dinilai hak seseorang dalam Negara demokrasi yang memang diakui dan dihargai.

Tentang dominannya tokoh-tokoh agama yang datang dari pemerintah di dalam MUI ini, Adam Malik pernah memberi komentar bahwa "hal itu sebagai kewajaran. Di manapun dan siapapun yang memerintah akan melakukan hal itu“. Pernyataan ini dapat di pahami dalam sistem pemerintah di Indonesia kini, tetapi dalam sejarah Islam pernah ada praktek lain. Khalifah Abd. Rahman III al-Nashir (Khalifah bani Umayyah di Andalus/Spanyol Islam) pernah di tanya oleh anaknya, Al-Hakam, perihal mengapa Khalifah tidak memecat Al-Mundzir Ibnu Sya'id ( Qadhi dan Imam Masjid Al-Azhar ) karena membantah kebijaksanaan yang ditempuh khalifah dalam membangun kota Al-Zahra. Khalifah menjawab: “Aku tidak memecat orang yang jujur dan baik hati, biarlah ia tetap sebagai Qadhi dan Imam Masjid Al-Azhar. Aku malu kepada Allah SWT. Untuk memecatnya tetapi mudah-mudahan Allah memberikan aku jalan untuk menebus kesalahanku".

\section{Program Kerja}

Program kerja hasil Munas I sifatnya masih sederhana dalam bentuk pokok-pokok yang terdiri dari :

1. Program ke dalam. Program ini lebih bersifat ingin mencari bentuk bagaimana MUI itu sebenarnya

2. Program ke luar. Program ini terdiri dari 4 hal: Pembangunan Nasional, Ketahanan Nasional, Kerukunan Umat Beragama, serta Peningkatan Kerja Ulama Umara'.

Program ini merupakan penjabaran lebih lanjut Dari Amanat Presiden ketika membuka Musyawarah Nasional seperti yang sudah di singgung ketika 
membahas Pedoman Dasar dan Pedoman Rumah Tangga MUI. Isi program kerja di titik beratkan agar MUI mampu sebagai penerjemah program yang ditetapkan oleh pemerintah demi kepentingan Nasional.

Program kerja Munas II pada hakekatnya adalah berupa penjabaran dari hasil Munas I, begitu juga yang terlihat pada hasil Munas III. Ada 4 tujuan program yang disusun dalam program kerja Munas II yang secara singkat berisi:

1. Menetapkan, meningkatkan dan mendayagunakan MUI sebagai Organisasi Ulama.

2. Menanamkan kesadaran hidup bernegara dalam tatanan masyarakat dalam warga Negara RI yang berfalsafah Pancasila.

3. Memantapkan dan meningkatkan kesadaran bernegara untuk menggalang kesatuan dan persatuan bangsa.

4. Ikut menyukseskan pembangunan manusia seutuhnya sehingga terwujud stabilitas Nasional.

Penjabaran tujuan program ini dibagi-bagi dalam program umum, dan perincian program. Sebagai program jangka pendek antara lain dirumuskan "Kursus Lokakarya bagi Muballigh untuk melengkapi dirinya sebagai penerjemah di lapangan perlu di perbanyak ilmunya. Bidang-bidang program terdiri dari Organisasi, Keagamaan, Ukhuwwah Islamiyah dan Pembangunan.

Tujuan program hasil Munas III terlihat lebih banyak diarahkan kepada ikut serta menciptakan kerangka landasan Pembangunan Nasional untuk lepas landas pada Pelita VI. Tujuan program ini terlihat pada tema Munas III yang berbunyi : Dengan pendalaman dan peningkatan peran serta umat, kita songsong lepas landas Pembangunan Nasional. Sasaran program khususnya dalam menyongsong dari depan dengan iman dan amalnya melaksanakan pembangunan nasional yang mempunyai dimensi keterkaitan antara kesejahteraan duniawi dan ukhrawi.

Dalam hal pelaksanaan program kerukunan antar umat beragama, khususnya kerukunan antar umat beragama dengan pemerintah, perlu di singgung di sini karena yang dikehendaki umat beragama di sini adalah umat Islam. Karena 
umat Islam merupakan mayoritas. Jika ini berhasil berarti agama lain akan dapat terselesaikan. Sedang tugas khusus yang disampaikan kepada Menteri Agama poin 3 yang berbunyi : "Menghilangkan segala keraguan dan kecurigaan yang sudah berjalan hampir 33 tahun antar umat beragama dengan pemerintah sehingga akhirnya umat beragama dengan pemerintah dapat bersama-sama membangun bangsa dan Negara berdasarkan pancasila.

Umat Islam sendiri, sebenarnya tidak perlu dicurigai, khususnya menyangkut kerukunan antar umat beragama, karena dalam ajarannya sendiri telah ada. Sikap tasamuh (toleransi) memang telah menjadi kepribadiannya asal saja tidak ada gangguan. Umat Islam telah menyepakati beberapa keputusan yang telah ditetapkan oleh Menteri Agama, seperti surat no.70 tahun 1980 tentang Pedoman Penyiaran Agama, surat no.77 tahun 1978 tentang Bantuan Luar Negeri kepada Lembaga keagamaan di Indonesia ditambah dengan Keputusan Bersama Menteri Agama dan Menteri Dalam Negeri no.1 tahun 1979 tentang Tatacara Pelaksanaan Penyiaran Agama dan Bantuan Luar Negeri kepada Lembaga Keagamaan di Indonesia. Namun demikian dapat dilihat berdasarkan hasil sensus, tahun 1971 umat Islam mencapai 87,5\% dari seluruh penduduk Indonesia tetapi pada tahun 1980 turun menjadi 87,1\% sedang Katolik dan Kristen tahun 1971 hanya mencapai 7,4\% pada tahun 1980 naik menjadi 8,8\%. Hindu mengalami kenaikan dari 1,9\% pada tahun 1971 menjadi 2,0\% pada tahun 1980 sedangkan Budha tetap 0,9\%. Faktor penyebab terjadinya perubahan prosentase pemeluk agama memang bisa bermacam-macam antara lain karena perpindahan penduduk, reklasifikasi suatu sekte tertentu, cakupan daerah sensus, kematian atau kelahiran dan perpindahan agama. Yang menjadi persoalan seberapa jauh pelaksanaan dan pengawasan surat-surat keputusan di atas. MUI sendiri baru tingkat "mendorong" berlakunya surat-surat keputusan itu. Pelaksanaannya masih tergantung pada penguasa (pemerintah ).

\section{Fatwa}


Sampai dengan akhir 1984 Majelis Ulama Indonesia telah mengeluarkan fatwa sebanyak 33 fatwa. Fatwa-fatwa ini telah dibukukan dalam bentuk kumpulan fatwa MUI. Yang di bagi dalam 3 bagian : Bagian Pertama Ibadah meliputi 12 fatwa, bagian kedua Kemasyarakatan meliputi 14 fatwa dan bagian ketiga Pengetahuan yang meliputi 7 fatwa. Kelahiran fatwa-fatwa tersebut jika dibaca konsiderannya sebagai jawaban atas pertanyaan yang di ajukan oleh individu dan lembaga swasta (5 fatwa), oleh aparat pemerintah (16 fatwa), oleh Dirjen Bimas Islam dan Urusan Hajji Departemen Agama (9 fatwa) sedang sisanya adalah inisiatif dari MUI sendiri.

Yang termasuk kategori fatwa ibadah, antara lain adalah :

a. Mensyukuri dan menghargai kegiatan pembesar-pembesar Negara yang sudah dilaksanakan di bidang tersebut.

b. Menganjurkan kepada para pembesar Negara, Pejabat pemerintah dan pimpinan-pimpinan seumumnya agar lebih giat mempelopori kegiatankegiatan peribadatan dengan cara-cara antara lain :

i. Mengadakan pengajian-pengajian/kursus-kursus agama untuk pribadi, dan kolega di kantor, dengan keluarga di rumah, serta pengajian dan ceramah agama buat seluruh pegawai karyawan di kantor.

ii. Dimana mungkin mengadakan sembahyang jum'at di kantor dan upacaraupacara Hari Besar Islam, menyembelih qurban dan mengumpulkan zakat harta atau fitrah oleh panitia-panitia dibawah bimbingan dan pengawasannya.

iii. Menjaga pantangan-pantangan Agama dan adat istiadat dikala berkunjung ke daerah.

iv. Mengumpulkan buku-buku tentang Islam dari bahasa Indonesia dan asing, karangan ulama-ulama dan sarjana-sarjana intelektual muslim, untuk perpustakaan kantor dan perpustakaan rumah.

v. Berlangganan secara massa abonnement majalah-majalah Islam untuk konsumsi pegawai dan karyawan serta ruangan tamu kantornya. 
vi. Dan lain-lain kegiatan dalam rangka pembangunan rohani yang berlandaskan ajaran Islam bagi sekalian pemeluknya

Fatwa ini ditujukan kepada umat islam pada umumnya dan khususnya bagi pejabat agar mau berda'wah lewat amal perbuatan sehingga dapat ditiru oleh bawahannya. Dalam sisi lain MUI memberi fatwa tentang Aliran yang menolak Sunnah/Hadits Rasululloh, sebagai berikut :

1. Aliran yang tidak mempercayai hadits nabi Muhammad s.a.w. sebagai sumber hukum syariat Islam, adalah sesat menyesatkan dan berada di luar Agama Islam.

2. Kepada mereka yang secara sadar atau tidak, telah mengikuti aliran tersebut, agar segera bertaubat.

3. Menyerukan kepada umat Islam untuk tidak terpengaruh dengan aliran yang sesat itu.

4. Mengharapkan kepada para ulama untuk memberikan bimbingan dan petunjuk bagi mereka yang ingin bertaubat.

5. Meminta dengan sangat kepada Pemerintah agar mengambil tindakan tegas berupa larangan terhadap aliran yang tidak mempercayai hadits Nabi Muhammad s.a.w. sebagai sumber syariat Islam.

Dalam hal ini Kemasyarakatan Majelis Ulama Indonesia berfatwa agar rakyat Indonesia mau hidup sederhana, dengan ringkasan fatwa sebagai berikut:

1. Menyambut baik dengan penuh penghargaan atas anjuran Presiden Republik Indonesia tentang hidup sehat.

2. Memperkuat anjuran Presiden tersebut dengan dalil-dalil agama.

3. Menganjurkan kepada Presiden agar melaksanakan:

1) Mengeluarkan intruksi kongkrit kepada pejabat-pejabat mengenai anjuran hidup sederhana dan pelarangan hidup mewah/berlebihlebihan. 
2) Menegaskan penegakan hukum terhadap semua pelanggar hukum tanpa pandang bulu sebagaimana yang dinyatakan oleh Jaksa Agung.

3) Memberatkan hukuman atas tindak pidana tersebut dengan perundangundangan seperlunya, antara lain dengan usaha memasukkan hukum pidana Islam.

4) Perbaikan Ekonomi umumnya terutama biaya hidup pegawai agar mereka tidak melakukan penyelewengan.

5) Mengawasi dengan keras dan ketat terhadap pelanggaran-pelanggaran hukum.

4. Menganjurkan kepada alim ulama, guru-guru, muballigh, khatib-khatib dan mass media untuk lebih menjelaskan ajaran Islam yang menganjurkan hidup sederhana dan melarang hidup mawah dan berlebih-lebihan terutama dari hasil pencaharian yang haram dan tidak syah.

Larangan-larangan di atas disamping dari anjuran Presiden RI, juga dikuatkan oleh firman Allah yang melarang akan pemborosan/tabzir, seperti diterangkan dalam surat Al-Isra' ayat 26-27 yang artinya sebagai berikut: “....Dan janganlah kamu menghambur-hamburkan (hartamu) secara boros. Sesungguhnya pemboros-pemboros itu adalah saudara-saudara syaitan, dan syaitan itu sangat ingkar terhadap tuhannya”. Dan juga larangan Allah agar tidak berlebih-lebihan/isyraf: "Jangan kamu turuti pekerjaan orang yang berlebihlebihan. Mereka itulah yang merusak di atas bumi dan tidak memperbaiki". (Surat Asy-Syu'ara', ayat 151-152). Dan Allah juga melarang suap-menyuap serta korupsi, dengan firmannya: "Dan janganlah kamu memakan harta sebagian yang lain di antara kamu dengan jalan yang batil, dan (janganlah) kamu membawa (urusan) harta itu kepada hakim-hakim, supaya kamu dapat memakan sebagian dari harta orang lain dengan (jalan berbuat) dosa, padahal kamu mengetahui.” (Al-Baqoroh, ayat 188). Dan larangan korupsi seperti firmannya yang artinya: "Dan janganlah seorang Nabi berhianat (korupsi) dan siapa-siapa yang korupsi maka pada hari kiamat akan membawa apa yang ia khianati, kemudian tiap-tiap 
orang akan dibalas apa-apa yang ia kerjakan dengan balasan yang setimpal. Dan mereka tidak di curangkan (Ali Imron, ayat 161). Dan perintah Allah untuk hidup sederhana seperti firmannya: "Dan janganlah kamu jadikan tanganmu terbelenggu ke lehermu (kikir), dan janganlah terlalu mengulurkannya (boros), agar kamu tidak menjadi tercela dan menyesal." (Al-Isro', ayat 29). "Dan orang-orang yang baik adalah yang apabila menyalurkan hartanya maka ia tidak berlebih-lebihan dan tidak terlalu pelit. Dan di antara kedua itulah yang paling baik.” (Al-Furqon, ayat 76).

\section{Kekurangan-kekurangan MUI}

Dari awal berdirinya Majelis Ulama Indonesia pada tahun1975 yang dikehendaki oleh pemerintah dan sebenarnya bukan sepenuhnya kehendak dari umat Islam Indonesia dan para Ulama Indonesia sampai dengan akhir tahun 1984, MUI baru mengeluarkan fatwanya sebanyak 33 fatwa, sebagaimana telah dikatakan di atas, yang telah dibukukan dalam bentuk kumpulan fatwa yang dibagi dalam 3 bagian :

1. Ibadah

2. Kemasyarakatan

3. Bidang pengetahuan

Dari sekian banyak fatwa, terdapat beberapa fatwa yang menggemparkan masyarakat Indonesia, pertama tentang fatwa halal dan haramnya hewan katak yang bermula dari fatwa Majelis Ulama daerah Sumatera Barat yang menyatakan tidak dijumpainya dalil yang shorih akan keharamannya. Fatwa berikutnya datang dari Majelis Ulama daerah Nusa Tenggara Barat yang menyatakan bahwa hewan katak itu haram untuk dimakan karena termasuk hewan yang hidup di dua alam atau dua tempat. Sebagai tanggapan terhadap kedua fatwa tersebut akhirnya MUI menfatwakan: "Membenarkan adanya pendapat Imam Syafi'i/Jumhur Ulama' tentang ketidak halalan memakan daging hewan katak, dan membenarkan pendapat Imam Maliki akan halalnya memakan daging hewan katak". Dari kejadian di atas, MUI baru merasa akan kekurangannya dalam mengemban tugas 
sebagai pembuat fatwa dan setelah kejadian itu MUI mengambil langkah: "Fatwa baru dapat diedarkan/diumumkan jika sudah ditanfidz oleh dewan pimpinan MUI”. Sedang pentanfidzan fatwa yang telah diterbitkan dalam bentuk buku, baru fatwa tentang katak. Fatwa kedua yang sempat menghebohkan adalah fatwa tentang perayaan Natal bersama yang akhirnya dicabut peredarannya, tetapi bukan isinya. Dari kasus fatwa Natal bersama ini Prof. Hamka mengundurkan diri dari jabatan Ketua MUI (1984). Fatwa ketiga yang sampai tahun 1990 belum kunjung tiba adalah fatwa tentang PORKAS. Ketua Umum MUI pernah menjanjikan akan mengeluarkan fatwa namun sampai tahun 1990 tidak kunjung tiba.

\section{Kelebihan-kelebihan MUI}

Dengan adanya MUI dapat memberikan pertimbangan mengenai masalah keagamaan dan kemasyarakatan kepada umat dan pemerintah dalam usaha meningkatkan Ketahanan Nasional dan sebagai wadah ukhuwah Islamiyah dalam rangka kerukunan antar umat beragama dalam mewujudkan persatuan dan kesatuan serta sebagai organisasi yang mewakili umat Islam dalam badan konsultasi antar umat beragama dan pengikut kepercayaan terhadap Tuhan Yang Maha Esa serta sebagai komunikator antar ulama dan pemerintah dan antara ulama dengan umat Islam guna menyukseskan Pembangunan Nasional.

Fungsi MUI sebagai penghubung antara ulama dan pemerintah serta sebagai penterjemah yang menyampaikan pikiran dan saran-saran yang berhubungan dengan pembangunan masyarakat. Bagaimanapun supaya terdapat koordinasi yang sebaik-baiknya antara pemimpin-pemimpin resmi dan tidak resmi, antara umara' dan ulama, koordinasi yang akan dapat saling menunjang bagi pelaksanan tugas masing-masing untuk mengambil bagian dalam pembangunann dan bagaimanapun diusahakan untuk menemukan bahasa yang lebih mantap sesuai dengan bahasa pembangunan yang diperlukan oleh masyarakat kita karena bahasa ini sangat penting dan sangat menentukan bagi tercapainya sasaran di bidang penerangan maupun di bidang dakwah yang menjadi lapangan para ulama, muballigh, dan da'i. Ulama sebagai penggungjawab 
Agama menurut Al-Ghazali, yang dijelaskan dalam kitab Ihya' Ulumuddin, jilid 1 h. 58-59, beliau membagi ulama' dalam dua macam :

1. Ulama' Ad-Dunya (Ulama' yang lebih banyak mengurus/menitikberatkan urusan dunia).

2. Ulama' Al-Akhirah (Ulama' yang banyak mengurus/menitikberatkan tentang urusan akhirat).

Sedangkan dalam hubungannya dengan penguasa, beliau (Imam Ghazali) membagi menjadi 3:

1. Ulama yang mendekati dan bekerjasama, dengan tujuan memberi nasihat bila pemerntah terlanjur berbuat salah, dengan harapan agar kembali kepada jalan yang lurus.

2. Ulama yang tidak mau bekerjasama namun masih menjaga nama baik diri dan pemerintah, jika penguasa mau mendatanginya maka dia merasa wajib untuk memberi nasihat ke jalan yang benar.

3. Ulama yang memisahkan diri dari penguasa yang tidak jujur, pemisahan ini diniati bukan karena manusia/ria'/takabbur, melainkan diniatkan karena Allah.

Dilihat dari penjelasan tersebut diatas maka ulama Indonesia yang penulis kehendaki disini, MUI adalah tergolong Ulama'Ad-Dunya wal Akhirah (Ulama yang ikut mengurus urusan dunia dan juga urusan akhirat). Dalam urusan dunia MUI ikut serta berpartisipasi dalam pembangunan manusia seutuhnya, rohani dan jasmani seperti mencerdaskan umat yang terlihat masa sekarang ini adalah sudah dilaksanakannya kader ulama yang mumpuni dalam urusan dunia yang sudah berjalan kurang lebih 3 tahun. Dalam urusan akhirat, MUI banyak mengeluarkan fatwanya mengenai ibadah, seperti fatwa tentang sholat jum'at bagi para musafir, do'a daf'ul bala', sholat dalam masjid yang bertingkat dan fatwa-fatwa lain yang tidak dapat kami sebutkan secara keseluruhan. Walaupun disana sini masih banyak kekurangan-kekurangannya yang dikarenakan kurangnya informasi ini dapat sampai pada masyarakat di daerah karena kurangnya dana. 
Organisasi MUI ini bila dibandingkan dengan ormas-ormas Islam lainnya maka akan nampak perbedaan. Pertama, organisasi MUI ini tidak berpolitik dan tidak operasional, dalam arti agar MUI ini dapat independen dalam melaksanakan tugas-tugasnya, hal ini juga dapat dimengerti, karena jika MUI ikut serta dalam berpolitik maka fungsi MUI sebagai pemberi nasehat kepada umat dan juga kepada pemerintah akan mengalami keganjilan-keganjilan dan akan sama fungsinya dengan ormas-ormas Islam lainnya. Demikian pula tidak bersifat operasional karena hal ini sudah dilaksanakan oleh ormas-ormas Islam yang ada di Negara Indonesia tercinta ini. Namun demikian nampak juga kelemahankelemahan yang terselip di dalamnya, seperti yang ditulis oleh Dr. Deliar Noor dalam bukunya "Administrasi Islam di Indonesia" :

"Perhatian MUI juga diberikan kepada masalah Pemilihan Umum pada tahun 1977. Majelis meminta perhatian semua pihak agar menghormati Undang-Undang dan peraturan yang berhubungan dengan Pemilihan Umum agar hasilnya diridloi oleh Allah. Setelah Pemilihan Umum majelis mencatat adanya pelanggaran dan majelis berkesimpulan bahwa pemilihan Umum tidak dilaksanakan dengan mengingat semangat dan kata-kata dari Undang-Undang bersangkutan serta peraturan pelaksanannya, Majelis mencatat adanya pelanggaran hukum yang dilakukan oleh aparat pemerintah, sebelum, sesudah dan ketika Pemilihan Umum berlangsung tanggal 2 Mei 1977. Majelis juga mengemukakan dalam hubungan ini betapa banyak khotib yang dilarang berkhotbah, Kyai yang dilarang mengajar". (Dr. Deliar Noor: 145)

Hal yang demikian ini bukan semata-mata merupakan kehendak MUI namun himbauan-himbauan MUI yang seharusnya dilaksanakan akan tetapi justru ditinggalkan. Dalam megembankan amanat MUI ini, jauh-jauh sebelumnya "Hamka" telah membuat ilustrasi dalam sambutannya di depan majelis :

'Kadang-kadang ulama'-ulama' benar-benar terletak di tengah-tengah laksana kue bika yang sedang dimasak dalam priuk belanga. Dari bawah dinyalakan api, api yang dari bawah itu ialah berbagai ragam keluhan rakyat dari atas dihimpit dengan api, api yang dari atas itu ialah harapanharapan dari pemerintah agar rakyat diinsafkan dengan bahasa rakyat itu sendiri. Dengan berat keatas niscaya putus dari bawah. Putus dari bawah niscaya berhenti dari ulama' yang didukung rakyat. Berat kepada rakyat, 
hilang hubungan dengan pemerintah, maksudnya tidak berhasil. Pihak pemerintah bisa saja mencap tidak berpartisipasi dengan pembangunan".

Dari hal-hal yang disampaikan diatas telah dapat diambil sarinya, baik mengenai segi pahitnya ataupun segi manisnya dalam pelaksanaan tugas Majelis Ulama' Indonesia.

\section{Daftar Pustaka}

Al Baidowi, (t.t), Anwar At-Tanzil wal Asro’'At-Takwil Al Musamma Tafsir Al Baidawi, Dar Al Fikr.

Al Badri, Abdul Aziz, 1987, Al Islam Bainal Ulama' wal Khukama', Alih Bahasa: Salih Muhammad Wahid. Pustaka Mantek, Solo.

Abu Al Yusr, Umamah Ibnu Muhammad Ibnu Al Karim, 1963, Ushul Addin, Darul Ihya' Al Kutub Al Arobiyah.

Biro Pustaka Statistik, 1984, Beberapa Ciri Pemeluk Agama di Indonesia, Jakarta.

Departemen Agama RI, 1982, Monografi Kelembagaan Agama di Indonesia.

Departemen Agama RI, 1985, Al Qur'an dan terjemahannya.

Ghazali, Al Imam, (t.t), Ihya' Ulumuddin jilid 1, Darul Ihya' Al Kutub Al Arobiyah.

Majelis Ulama’ DKI Jakarta, 1985, Rangkaian Fatwa/Keputusan.

Noor, Deliar, 1983, Islam; Pancasila; dana Asas Tunngal, Yayasan Perhidmatan, Jakarta.

Noor, Deliar, 1983, Administrasi Islam di Indonesia, Rajawali, Jakarta.

Pustaka Panji Mas, 1984, Kumpulan Fatwa MUI, Jakarta.

Sekretariat MUI, Masjid Agung Al Azhar, 1976, Majelin Ulama' Indonesia, Kebayoran Baru, Jakarta Selatan

Sekretariat MUI, 1980, Keputusan-keputusan Munas II MUI. 